\title{
Prediction of Early Season Beet Leafhopper Populations in Southern New Mexico
}

\author{
Erik Lehnhoff and Rebecca Creamer ${ }^{\dagger}$ \\ Department of Entomology, Plant Pathology, and Weed Science, New Mexico State University, Las Cruces, NM 88003
}

Accepted for publication 30 January 2020.

\begin{abstract}
Curly top is an important widespread disease in semiarid regions that can be caused by several Curtovirus and Becurtovirus species. The strains of beet curly top virus (BCTV) have been some of the most widely reported to be associated with curly top. The viruses causing curly top are phloem limited and transmitted by the beet leafhopper (BLH), Circulifer tenellus Baker (Hemiptera: Cicadellidae). The BLH can also transmit other important pathogens such as phytoplasmas. Both the virus and insect vector have a broad host range of crops and weeds, including the winter annual weed London rocket (Sisymbrium irio L.). Prior prediction of disease would allow growers a window of opportunity to make informed management choices. A prediction model of BLH abundance was developed for southern New Mexico based on fall precipitation, which corresponds with London rocket emergence, and BLH sticky trap catch data for 2001 to 2018. Regression analyses showed

positive associations between BLH numbers and October + November rainfall $(P<0.001)$ for two areas within southern New Mexico. A third area, where good weed management was used, had lower BLH numbers, and the relationship with precipitation was not significant $(P=0.190)$. Cumulative-season BLH abundance was correlated with BLH abundance in late April $(r=0.43)$ and late May $(r=0.56)$, indicating that early season knowledge of BLH abundance is useful for planning later season management. Although models based on October + November precipitation are good predictors of BLH abundance through June, they may not predict year-long BLH abundance because other environmental and biological factors contribute to subsequent BLH success and movement.

Keywords: beet curly top virus, BCTV, Circulifer tenellus, disease epidemiology, London rocket, Neoaliturus tenellus, Sisymbrium irio
\end{abstract}

Curly top disease is caused by beet curly top viruses (BCTVs), which are viruses within the family Geminiviridae, genus Curtovirus, that are phloem-limited viruses transmitted by the beet leafhopper (BLH), Circulifer (= Neoaliturus) tenellus (Baker) (Hemiptera, Cicadellidae) (Bennett 1971). Curtoviruses infect a broad range of crop and weed hosts, routinely causing losses in California, Arizona, Texas, Colorado, Idaho, and New Mexico, on crops such as tomatoes (Solanum lycopersicum L.), sugar beets (Beta vulgaris L.), dry beans (Phaseolus spp.), spinach (Spinacia oleracea L.), melons, and peppers (Capsicum spp.) (Chen et al. 2010; Sedano et al. 2012; Strausbaugh et al. 2017). In New Mexico, curly top has caused significant damage to chile peppers and tomatoes, with losses to chile peppers ranging from 30 to $50 \%$ in 2001 to 0.5 to $1 \%$ in 2002 (Creamer et al. 2003). Symptoms of BCTV in chile pepper include severe stunting of plants, chlorosis, stiff stems, and brittle leaves. Curly top-infected chile produce small misshapen fruit or no fruit.

Weed species from New Mexico that have been found infected with curtoviruses include London rocket (Sisymbrium irio L.), kochia (Kochia scoparia [L.] Schrad.), Russian thistle (Salsola tragus L.), prostrate pigweed (Amaranthus blitoides S. Wats.), spurred anoda (Anoda cristata [L.] Schlecht.), Datura sp.,

${ }^{\dagger}$ Corresponding author: R. Creamer; creamer@nmsu.edu

The author(s) declare no conflict of interest.

(C) 2020 The American Phytopathological Society
Chenopodium sp., and morning glory (Ipomoea sp.) (Creamer et al. 2003; Lam et al. 2009). London rocket and kochia were found with the highest percentage of infection from field-collected samples.

The BLH, which is the only known vector of curly top virus species along with some phytoplasmas in North America, prefers arid and semiarid regions of the western and southwestern United States (Cook 1967). The BLH feeds and breeds on a wide range of host plants and can transfer virus to plant hosts upon which it cannot complete its life cycle (Hudson et al. 2010). For example, chile peppers and tomatoes are infected with BCTV in the field, but few eggs are laid on the plants, and those eggs do not hatch. Adults caged onto the plants for $24 \mathrm{~h}$ suffer very high (90\%) mortality (Hudson et al. 2010).

The BLH overwinters in southern New Mexico on weed species within the Brassicaceae and Chenopodiaceae. The winter annual weed London rocket appears to serve as the primary overwintering host. It is often the first weed host to emerge in the fall and is commonly found in open and disturbed areas and is highly prevalent. Studies of the seasonal phenology and distribution of London rocket in southern New Mexico established the temperature and moisture requirements for emergence, how growth and life cycle are affected by emergence date, and how BLH survival on caged London rocket is affected by emergence date (Ray et al. 2005). Field experiments showed that London rocket emergence was higher in October-planted seed than Decemberplanted seed (Ray et al. 2006). October-planted London rocket survived an average of 185 days, until mid to late April, which is 
sufficient time to serve as an overwintering host for the BLH. After the plants desiccate in mid-April to mid-May, the BLH moves onto susceptible, newly germinated crop plants and spring and summer weed hosts (Davis 2010). In 2009 to 2010, BLH adults were identified on London rocket from October through May to mid-June in southern New Mexico, when the plants desiccated.

We have monitored the adult BLH presence in southern New Mexico using yellow sticky traps since 2001 (Creamer et al. 2003). Traps provide information on localized movement of BLH adults because only the adults fly. BLH adults are relatively good flyers and fly in low-wind conditions (Klein 1992). Leafhopper trap counts have generally correlated with curly top incidence; large numbers of leafhoppers have been collected in years with high curly top levels. Trap counts show that initial peaks of leafhopper flights begin in mid-April to mid-May most years. This generally corresponds with the dry down of London rocket and winter annual weeds. The objective of this work was to determine if BLH counts from traps in the spring (March 1 to June 15) could be correlated with precipitation events from the previous fall (September to November), which may have triggered emergence of winter annual weeds such as London rocket.

\section{Data Collection}

BLHs were sampled from numerous fields in southern New Mexico from 2001 to present (Table 1). As previously reported (Creamer et al. 2003), incidence of leafhoppers in chile was assayed by trapping insects from the margins of chile fields. Because chile is not usually grown in the same field in consecutive years,

\begin{tabular}{|c|c|c|c|}
\hline \multicolumn{4}{|c|}{$\begin{array}{c}\text { TABLE } 1 \\
\text { Number of sites (farms) sampled annually for beet } \\
\text { leafhoppers at three locations }\end{array}$} \\
\hline \multirow[b]{2}{*}{ Year } & \multicolumn{3}{|c|}{ Location of farms } \\
\hline & Las Cruces & Hatch & Deming \\
\hline $2001^{\mathrm{a}}$ & 1 & 3 & 5 \\
\hline 2002 & 1 & 4 & 5 \\
\hline 2003 & 1 & 4 & 5 \\
\hline 2004 & 1 & 4 & 5 \\
\hline 2005 & 1 & 4 & 5 \\
\hline 2006 & 1 & 4 & 5 \\
\hline 2007 & 1 & 4 & 5 \\
\hline 2008 & 1 & 4 & 5 \\
\hline $2009^{b}$ & 2 & $\mathrm{ND}^{\mathrm{c}}$ & ND \\
\hline 2010 & 2 & ND & ND \\
\hline 2011 & 2 & ND & ND \\
\hline 2012 & 2 & ND & ND \\
\hline 2013 & 2 & ND & ND \\
\hline 2014 & 2 & ND & ND \\
\hline 2015 & 2 & ND & ND \\
\hline 2016 & 2 & ND & ND \\
\hline 2017 & 2 & ND & ND \\
\hline 2018 & 1 & ND & ND \\
\hline
\end{tabular}

a Samples were collected every 2 weeks from March 1 to June 15 during 2001 to 2008.

${ }^{\mathrm{b}}$ Samples were collected weekly from March 1 to June 15 during 2009 to 2018.

${ }^{\mathrm{c}} \mathrm{ND}=$ no data chile fields selected were located near those sampled in the previous year. Four yellow sticky traps $(20 \times 25 \mathrm{~cm})($ Hummert International, Earth City, MO) were placed approximately $61 \mathrm{~cm}$ from the ground at the margins of each test field. Traps were changed every 2 weeks from March 1 through June 15 from 2001 to 2008 and leafhoppers identified and counted. Traps were changed weekly from 2009 to 2018 during the same time period. We sampled fields in Deming, Las Cruces, Hatch, Garfield, Rincon, and Salem, New Mexico from 2001 to 2008 (Fig. 1, Table 1). For the analysis, all Deming sites were grouped as "Deming," the two Las Cruces sites were grouped as "Las Cruces," and the Hatch, Garfield, Rincon, and Salem sites were grouped together as "Hatch Valley." Only the two Las Cruces sites were sampled from 2009 to 2018 (Table 1). With the exception of one Las Cruces site, there were no management efforts directed at reducing BLH populations. At the Las Cruces site sampled from 2001 to 2018, extensive management (i.e., removal) was conducted on BLH weed hosts both within the farm and around the farm border. Precipitation data were gathered from weather stations (Spectrum Watchdog, Aurora, IL) located near the chile field sites.

\section{Regression Models and Correlations}

BLH abundance was modeled via generalized linear mixed models as a function of fall precipitation and location (Deming, Las Cruces, or Hatch Valley) using the package Generalized Linear Mixed Models using Template Model Builder (glmmTMB) (Brooks et al. 2017) in the statistical computing package R (R Core Team 2018). The number of farms sampled at the different locations (Deming, Hatch Valley, and Las Cruces) changed over time (Table 1), resulting in a different number of data points for each analysis. Each data point in the models represented a unique precipitation $\times$ site value, and sites without data were omitted from each data set, so there were no missing values in the analyses. Models were validated by evaluating plots of fitted versus residual values and by checking for overdispersion. Models using Poisson distribution were overdispersed, so a negative binomial distribution was used, allowing the variance to increase quadratically with the mean (Hardin and Hilbe 2007). Models included precipitation interacting with location as main effects and random effects of individual sites nested within location to account for site variability within location. BLH counts were transformed by adding 1 to all values to avoid the mathematical error of logging zero values in the models. Two BLH abundance values were determined to be statistical outliers, which led to problems with model convergence; thus, these values, including 4,104 at Rincon in 2001 and 2,687 at Garfield in 2001, were removed from the analyses. Initial models evaluated precipitation over discrete time periods (i.e., September, October, and November) to assess impacts on cumulative (April to June) BLH counts.

Subsequent models focused on combined October and November precipitation and expanded the analysis to evaluate impact on BLH abundance in different biweekly periods. We evaluated the time periods of April 1 to 15 and April 16 to 31 as early season BLH abundances and May 16 to 31 and June 16 to 30 as late season abundances.

Correlations of early season BLH abundance (based on counts in 2-week periods) with cumulative (i.e., full season; March 1 to June 15) BLH numbers were determined by Pearson's correlation coefficients using the "cor" function in R. For these analyses, BLH abundance from a discrete time period (e.g., April 1 to 15) was correlated with the cumulative amount of BLH minus the abundance in the 2-week time period being correlated. The dates of April 
1 to 15 , April 16 to 30 , and May 16 to 31 were used in the correlations because these dates had the most complete data throughout the years.

\section{Effects of Precipitation on BLH Abundance}

The effects of precipitation on cumulative BLH abundance varied by location and by the month in which the precipitation fell. September precipitation did not predict BLH abundance at any location (Fig. 2A). BLH abundance increased with October precipitation at Deming $(P=0.003)$ and Hatch Valley $(P<0.001)$ sites but not at Las Cruces $(P=0.202$; Fig. $2 B)$. This is likely because of the extensive weed management conducted at one Las Cruces site, which reduced BLH weed hosts and thereby
BLH abundance. BLH abundance increased with November precipitation at both Deming $(P<0.001)$ and Las Cruces $(P=0.048$; Fig. 2C). There were not enough September or November precipitation data points at the Hatch Valley sites to model. Although September precipitation did not predict BLH abundance, cumulative October and November precipitation did, with rainfall positively correlated with BLH abundance at Deming $(P<0.001)$ and Hatch Valley $(P<0.001)$ sites but not at Las Cruces $(P=$ 0.190; Fig. 3).

Although the data show that location is an import factor in predicting the effects of precipitation on BLH abundance, it is useful to have a more general model to predict BLH abundance. Removing the factor of location, the general model that best predicts

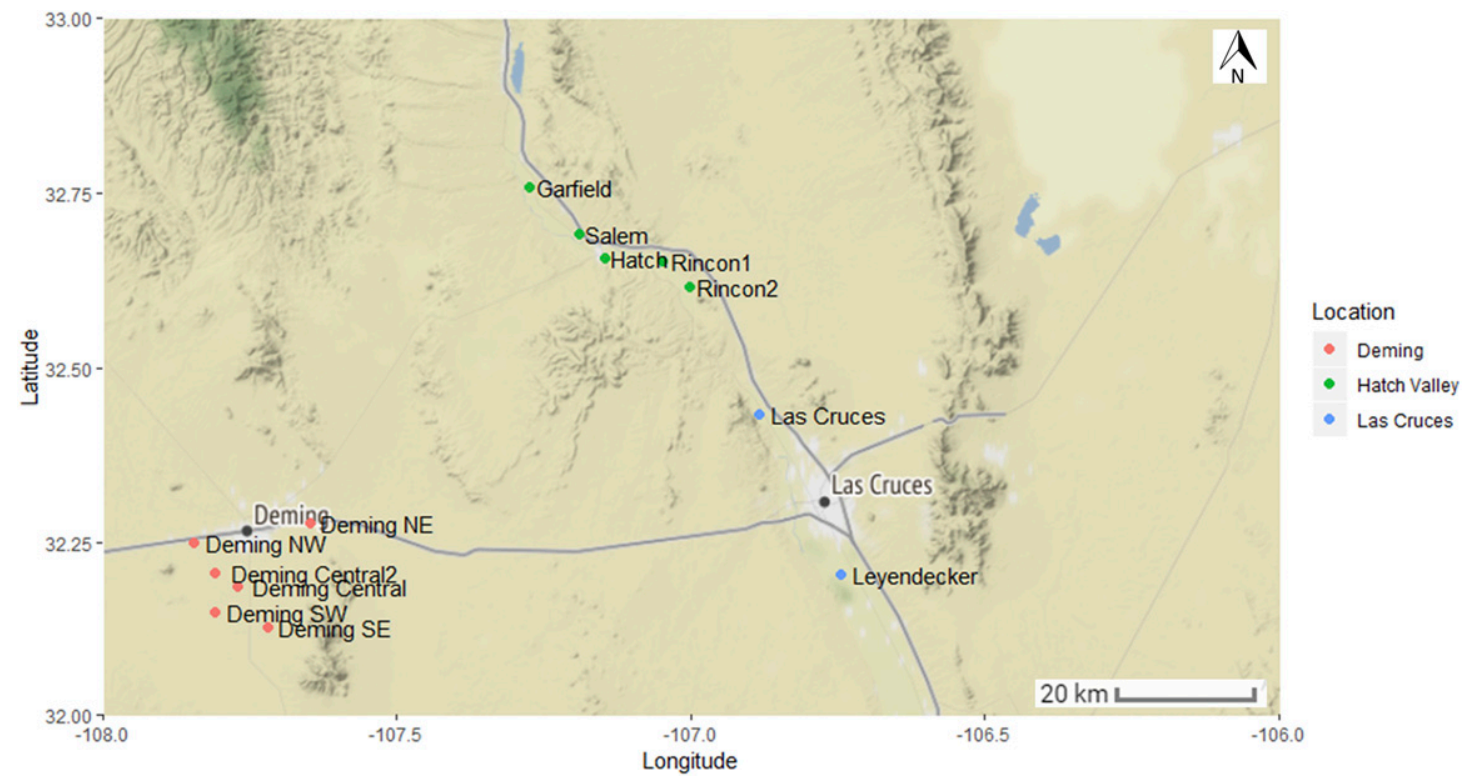

FIGURE 1

Site location of beet leafhopper sampling in southern New Mexico. Each dot represents an individual farm which was sampled, and dots are color coded by area.

A

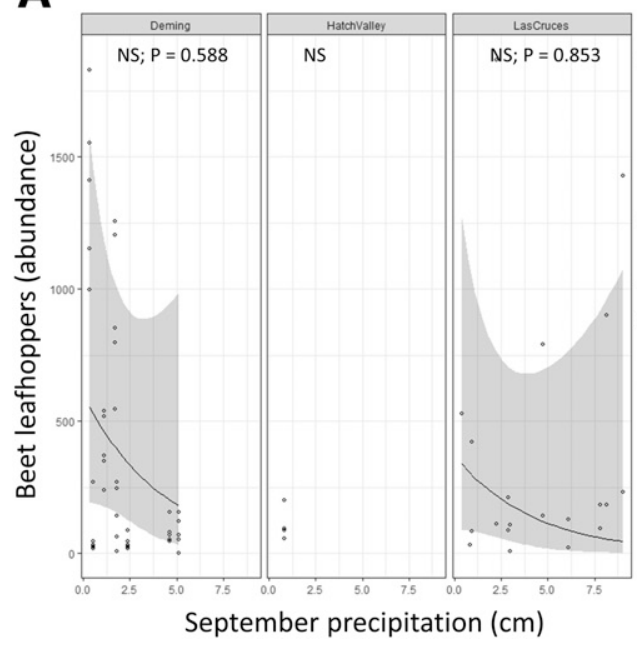

B

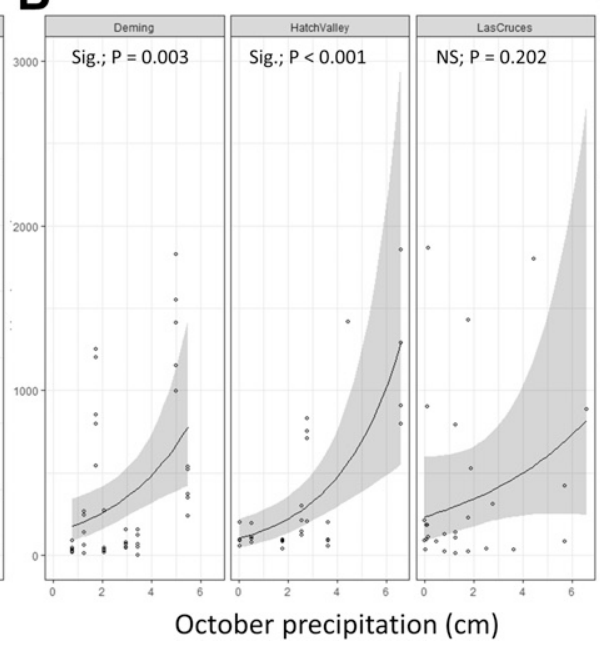

C

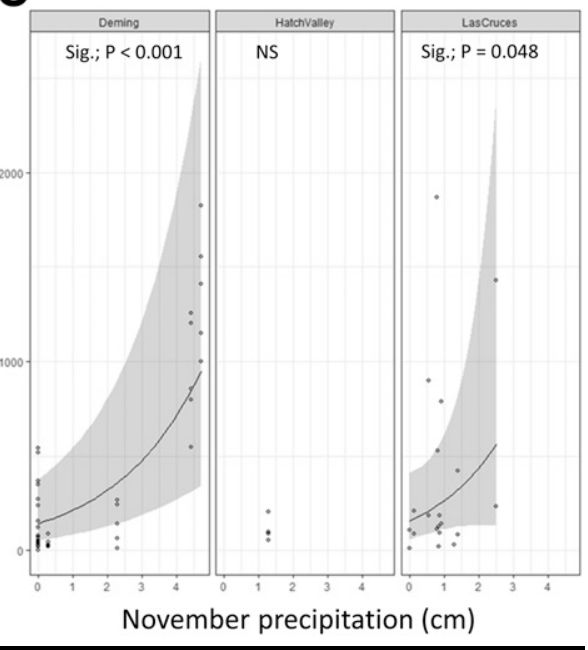

FIGURE 2

Generalized linear mixed model predictions of beet leafhopper abundance based on A, September, B, October, and C, November precipitation from 2001 to 2018 at three sites (Deming, Hatch Valley, and Las Cruces) in southern New Mexico. NS and Sig indicate not significant and significant at $P=0.05$, respectively. When $P$ values are not provided, there were not enough data points to fit a model. The shaded area indicates \pm 1 standard error of the mean. 
cumulative BLH abundance from March 1 to June 15 was as follows:

$$
\mathrm{BLH}=3.187+0.487 \times \exp ^{\Sigma(\text { October November precipitation })}
$$

The BLH abundance within discrete time periods in the spring was also predicted by cumulative October and November precipitation. The BLH abundance from April 1 to 15 increased with precipitation at Deming $(P<0.001)$ and Las Cruces sites $(P<$ $0.001)$ but not Hatch Valley $(P=0.073$; Fig. 4A). May 1 to 15 , May 16 to 31 , and June 1 to 15 BLH abundance increased with precipitation at Deming $(P<0.001)$ and Hatch Valley $(P<0.001)$ sites but not at Las Cruces $(P=0.631,0.076$, and 0.844 , respectively; Fig. 4B to D). Although precipitation did predict BLH abundance in early April at Las Cruces, weed management at one Las Cruces site likely led to fewer BLHs later in the season and, thus, a lack of correlation between fall precipitation and late spring BLH abundance.

Early April BLH abundance was a poor predictor of cumulative BLH abundance with a correlation of 0.35 (Fig. 5A), and the relationship was not significant $(P=0.279)$. Abundances of BLH from April 16 to 30 and May 16 to 31 were better predictors of cumulative BLH abundance with correlations of $0.43(P<0.001)$ (Fig. 5B) and $0.56(P<0.001)$ (Fig. 5C), respectively. Nonetheless, correlations ranged from very weak (April 1 to 15) to weak (April 16 to 30 ) and moderate (May 16 to 31 ), indicating that early season
BLH counts cannot necessarily be used to predict total BLH abundance, but counts in late April through late May could be useful predictors.

\section{Implications for Management}

The BLH life cycle in southern New Mexico is dependent upon the winter annual weed London rocket, which in turn is dependent upon October and November precipitation. Greater precipitation during these months leads to increased London rocket germination and survival and hence higher BLH abundance. Although the effects of precipitation are area specific, models indicate that $\mathrm{cu}-$ mulative October and November precipitation can be used to predict BLH abundance during the initial peak of leafhopper flights, which is typically in June but varies based on the date of London rocket senescence. Greater BLH abundance in the spring leads to a higher rate of BLH feeding on chile and higher incidence of BCTV.

These models do not predict the total BLH numbers for the entire year, or even the entire chile-growing season. In southern New Mexico, chile is usually planted in late March to early April and harvested late August through late September. The model predicts BLH abundance during London rocket growth, which lasts October through mid-June. After London rocket desiccates, the BLHs move onto other weeds including Kochia scoparia, where they can theoretically survive until fall (Davis 2010). Prediction of curly top disease and total BLH numbers will thus require more information

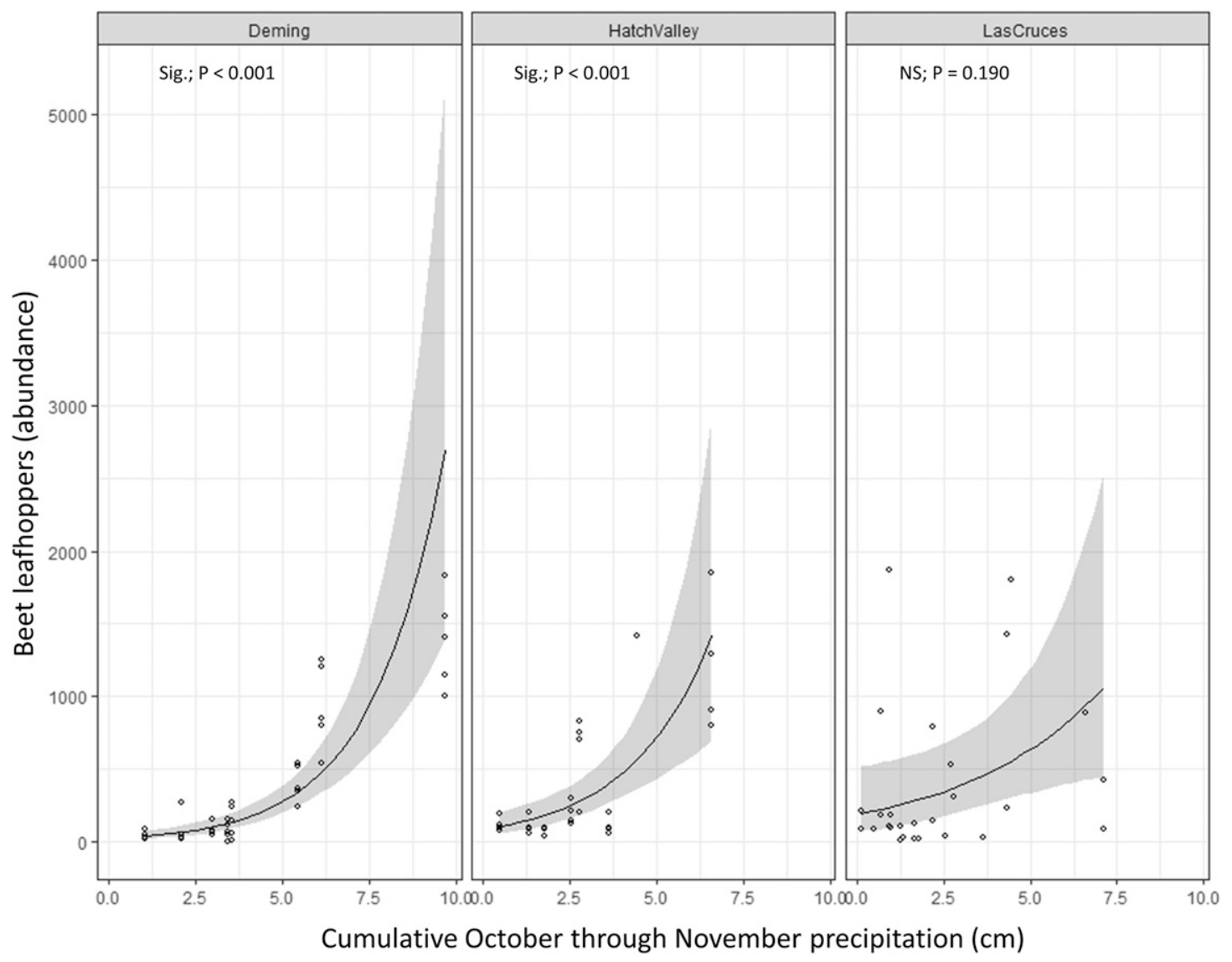

FIGURE 3

Generalized linear mixed model predictions of beet leafhopper abundance based on yearly cumulative October and November precipitation from 2001 to 2018 at three sites (Deming, Hatch Valley, and Las Cruces) in southern New Mexico. NS and Sig indicate not significant and significant at $P=0.05$, respectively. The shaded area indicates \pm 1 standard error of the mean. 
on the factors that influence leafhopper flights within a season. Those factors could include suitability of a particular host, host age, precipitation, temperature, and so on.

Climate change has had an effect on the epidemiology of the BLH as a vector of curly top and is likely to impact the BLH and disease in the future. During the course of this study, the average annual temperature increased and with it the total number of days over $38^{\circ} \mathrm{C}\left(100^{\circ} \mathrm{F}\right)$. In 2008 and 2009 , kochia, a likely BLH summer host, germinated in southern New Mexico in early to midApril, whereas in 2016 and 2017, the plants were first observed by the end of January to early February (Davis 2010; Dobey 2017).
Climate change is expected to cause dryer springs that begin earlier in the Southwestern United States and a change in the seasonality of precipitation (Garfin et al. 2013). This indicates an important avenue for future research, which should assess precipitation effects on both the senescence of London rocket in the spring and the germination and subsequent phenology of kochia in the summer, and how these factors are altered by a changing climate. These data will facilitate better predictions of when BLHs begin spring flights based on London rocket senescence and also provide clues to their population longevity during the summer as they survive on kochia.
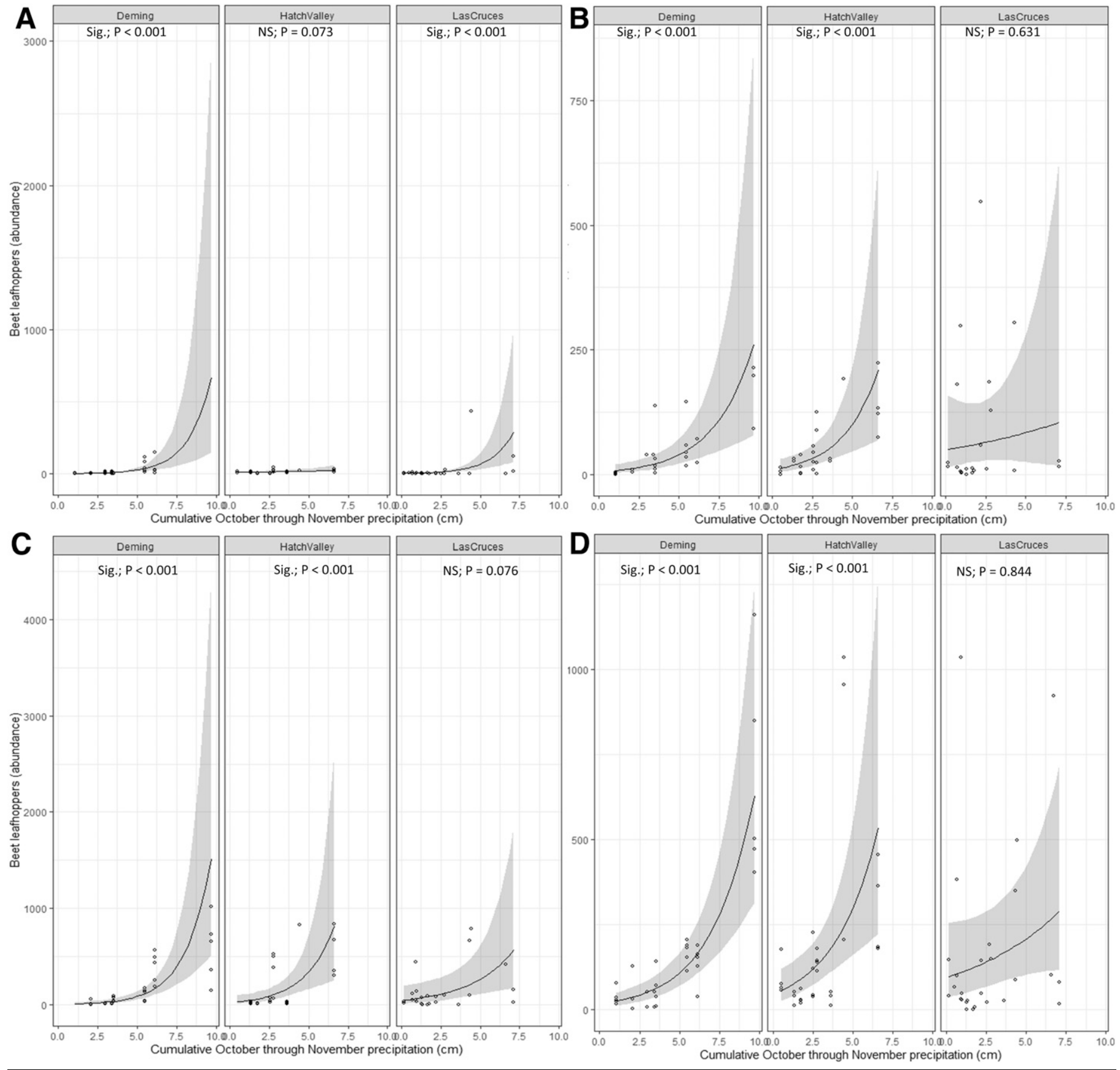

FIGURE 4

Generalized linear mixed model predictions of beet leafhopper abundance for the dates of A, April 1 to 15 , B, April 16 to $30, \mathbf{C}$, May 16 to 31 , and D, June 1 to 15 based on yearly cumulative October and November precipitation from 2001 to 2018 at three sites (Deming, Hatch Valley, and Las Cruces) in southern New Mexico. NS and Sig indicate not significant and significant at $P=0.05$, respectively. The shaded area indicates \pm 1 standard error of the mean. 

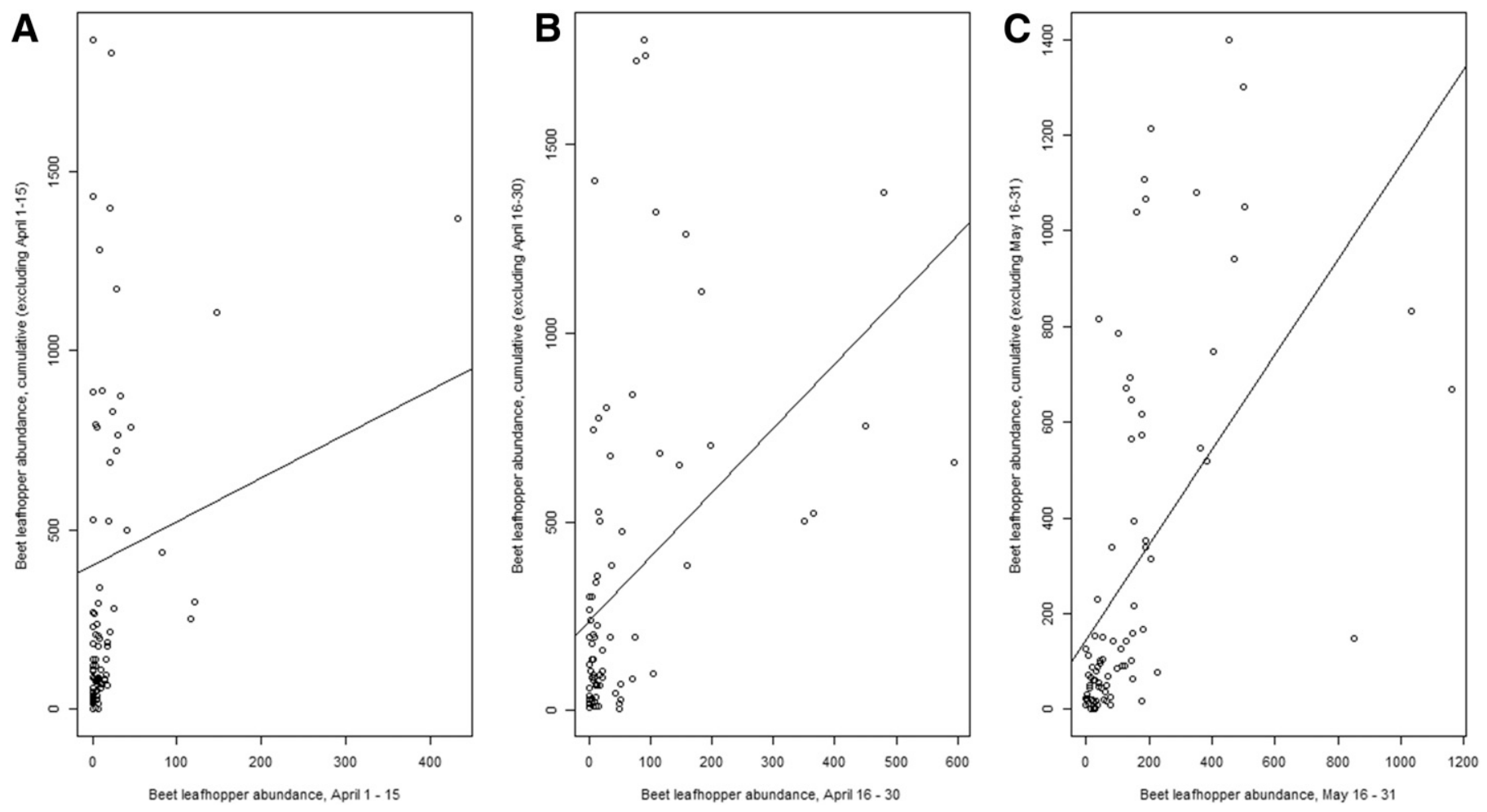

FIGURE 5

Correlations between beet leafhopper abundance in A, April 1 to 15, B, April 16 to 30, and C, May 16 to 31 and cumulative leafhopper abundance at three sites (Deming, Hatch Valley, and Las Cruces) in southern New Mexico. Correlations for April 1 to 15, April 16 to 30, and May 16 to 31 were 0.35 , 0.43 , and 0.56, respectively.

The BLH prediction model presented here will allow growers in the region to make informed decisions on weed management during the winter, prior to planting of their crops, ultimately facilitating reduction in BLH abundance and curly top. Additional research will be necessary to determine the optimal timing for removal of London rocket to have the maximum impact on BLH numbers. The information should also help growers plan insect and disease management, which could include delayed planting, using high seeding rates, using barriers such as row covers, or treating with kaolin clay to decrease the attractiveness of the plant to BLH (Creamer et al. 2005; Goldberg 2001).

\section{Literature Cited}

Bennett, C. W. 1971. The Curly Top Disease of Sugarbeet and Other Plants. Monograph 7. American Phytopathological Society, St. Paul, MN

Brooks, M. E., Kristensen, K., van Benthem, K. J., Magnusson, A., Berg, C. W., Nielsen, A., Skaug, H. J., Maechler, M., and Bolker, B. M. 2017. glmmTMB balances speed and flexibility among packages for zero-inflated generalized linear mixed modeling. R J. 9:378-400.

Chen, L. F., Brannigan, K., Clark, R., and Gilbertson, R. L. 2010. Characterization of curtoviruses associated with curly top disease of tomato in California and monitoring for these viruses in beet leafhoppers. Plant Dis. 94: 99-108.

Cook, W. C. 1967. Life History, Host Plants, and Migrations of the Beet Leafhopper in the Western United States. Tech. Bull. 1365. U.S. Department of Agriculture, Washington, DC.

Creamer, R., Carpenter, J., and Rascon, J. 2003. Incidence of the beet leafhopper, Circulifer tenellus (Homoptera: Cicadellidae) in New Mexico chile. Southwest. Entomol. 28:177-182.

Creamer, R., Sanogo, S., El-Sebai, O., Carpenter, J., and Sanderson, R. 2005. Kaolin-based foliar reflectant affects physiology, incidence of Beet curly top virus, but not yield of chile pepper. Hortic. Sci. (Prague) 40: 574-576.
Davis, G. 2010. Seasonal phenology of the beet leafhopper, Neoaliturus tenellus (Ball) (Hemiptera: Cicadellidae), on London rocket, Sysimbrium irio L., and Kochia, Kochia scoparia (L.), Schrader, in southern New Mexico. M.S. thesis. New Mexico State University, Las Cruces, NM.

Dobey, Q. 2017. Kochia germination requirements and the beet leafhopper preference towards kochia. M.S. thesis. New Mexico State University, Las Cruces, NM.

Garfin, G., Jardine, A., Merideth, R., Black, M., and LeRoy, S., eds. 2013. Assessment of Climate Change in the Southwest United States: A Report Prepared for the National Climate Assessment. Island Press, Washington, DC.

Goldberg, N. 2001. Curly top virus. Guide H-106. New Mexico State University, Las Cruces, NM.

Hardin, J. W., and Hilbe, J. M. 2007. Generalized Linear Models and Extensions. Stata Press, College Station, TX.

Hudson, A., Richman, D. B., Escobar, I., and Creamer, R. 2010. Comparison of the feeding behavior and genetics of beet leafhopper (Circulifer tenellus, Baker) populations from California and New Mexico. Southwest. Entomol. 35:241-250.

Klein, M. 1992. Role of Circulifer/Neoaliturus in the transmission of plant pathogens. Adv. Dis. Vector Res. 9:151-193.

Lam, N., Creamer, R., Rascon, J., and Belfon, R. 2009. Characterization of a new curtovirus, Pepper yellow dwarf virus, from chile pepper and distribution in weed hosts in New Mexico. Arch. Virol. 154:429-436.

R Core Team. 2018. R: A Language and Environment for Statistical Computing. R Foundation for Statistical Computing, Vienna, Austria. URL https:// www.R-project.org/.

Ray, J., Creamer, R., Schroeder, J., and Murray, L. 2005. Moisture and temperature requirements for London rocket (Sisymbrium irio) emergence. Weed Sci. 53:187-192.

Ray, J., Schroeder, J., Creamer, R., and Murray, L. 2006. Planting date affects phenology of London rocket (Sisymbrium irio) and interaction with beet leafhopper (Circulifer tenellus). Weed Sci. 54:127-132.

Sedano, M., Lam, N., Escobar, I., Cross, T., Hanson, S. F., and Creamer, R. 2012. Application of vascular puncture for evaluation of curtovirus resistance in chile pepper and tomato. J. Phytopathol. 160:120-128.

Strausbaugh, C. A., Eujayl, I. A., and Wintermantel, W. M. 2017. Beet curly top virus strains associated with sugar beet in Idaho, Oregon and a western U.S. collection. Plant Dis. 101:1373-1382. 